\title{
Deneyimsel Bir Hizmet Uzantısı Olarak Okunabilirlik: Seminerlerin Okunabilirlik Boyutlarının Belirlenmesine Yönelik Bir Çalışma
}

Legibility as an Experiential Servicescape: A Study on Determination of Seminars' Legibility Dimensions

\author{
Deniz KARAGÖZ*, Nazmi KOZAK** \\ *Yrd. Doç. Dr., Anadolu Üniversitesi, Turizm Fakültesi, Turizm İşletmeciliği Bölümü, Yunusemre Kampüsü, 26470, Eskişehir. \\ E-posta: dkaragoz@anadolu.edu.tr \\ **Prof. Dr., Anadolu Üniversitesi, Turizm Fakültesi, Turizm İşletmeciliği Bölümü, Yunusemre Kampüsü, 26470, Eskişehir. \\ E-posta:nkozak@anadolu.edu.tr
}

\begin{abstract}
MAKALE BILGILERI
Makale işlem bilgileri:

Gönderilme tarihi: 20 Nisan 2012

Birinci değerlendirme: 20 Temmuz 2012

İkinci değerlendirme: 10 Mayıs 2013

Üçüncü değerlendirme: 25 Kasım 2013

Kabul: 28 Kasım 2013
\end{abstract}

Anahtar sözcükler:

Hizmet uzantıları, Okunabilirlik,

Etkinlikler, Seminerler.

\section{ÖZ}

Çalışmanın temel amacı, iş amaçlı etkinliklerden biri olan seminerlerin okunabilirlik boyutlarının belirlenmesidir. Genel anlamda fiziksel mekânların okunabilirlik algısının incelendiği araştırmalardan farklı olarak; bu çalıșmada iș amaçıı bir etkinlik olarak tanımlanan seminerlerin okunabilirlik boyutlarının belirlenebilmesi için bir ölçek geliştirilmiştir. Ayrıca çalışma, geleneksel olarak incelenen fiziksel mekânların yanı sıra etkinlik web sitesi gibi sanal bir mekânının da değerlendirmeye alınması açısından önem taşımaktadır. Veriler Antalya'da düzenlenen VII. Araștırma Yöntemleri Semineri'nin katılımcılarından toplanmıștır. Yüz yüze uygulanan anket tekniği ile toplam 137 seminer katılımcısından veri elde edilmiştir. Verilerin analizi amacıyla açıklayıcı ve doğrulayıcı faktör analizlerinden yararlanıımıştır. Çalışma kapsamında organizasyonel açıklık, yol ve yön bulma, işaretlendirme, mekânsal düzenleme, bilgilendirme ve araçlar seminerin okunabilirlik boyutları olarak belirlenmiștir.

\section{ARTICLE INFO}

Article history:

Submitted: 20 April 2012

Resubmitted: 20 July 2012

Resubmitted: 10 May 2013

Resubmitted: 25 November 2013

Accepted: 28 November 2013

Key words:

Servicescapes, Legibility, Events,

Seminars.

\section{ABSTRACT}

This study aims to determine the dimensions of the legibility of the seminars as business events. Apart from the studies on the legibility of physical spaces in literature, the purpose of the study is to develop a scale for determining the legibility dimensions of seminars as a form of business events. Besides the physical spaces which are conventionally investigated, this study is important in terms of its inclusion of virtual spaces such as event web sites. Data was collected from the participants of the 7th Research Methodology Seminars held in Antalya. Face to face survey resulted in 137 completed questionnaires. Exploratory and confirmatory factor analyses were employed to analyze the data. The analyses revealed that organizational openness, path finding, signage, spatial layout, information and devices were legibility dimensions of seminars.

\section{GíRiş}

Hizmetlerin büyük oranda soyut olması ürün ya da ürünlerin değerlendirilmesinde müşteri deneyimini ön plana çıkarmaktadır. Ayrıca hizmetler tüketim öncesi, müşteriler tarafından denenememekte ve test edilememektedir. Hizmetlerin açıklanan bu özellikleri nedeniyle müşteriler, tüketim öncesi hizmetlerin değerlendirilmesinde kalite alg1sı ola- rak deneyimsel bileşenleri, yani hizmet uzantılarını değerlendirme eğilimindedirler. Hizmet uzantılarının özellikle de temel deneyimsel bileşenlerden biri olarak kabul edilen okunabilirlik yapısının anlaşılmasının ve etkin bir şekilde yönetilmesinin, etkinlik organizasyon işletmeleri ile turizm işletmelerinin müşterilerine zengin deneyimler sunabilmelerinde ve satışlarını artırmada olumlu katkı sağlayacağı söylenebilir. 
Bir mal ya da hizmetin sunum sürecini zenginleştirmek amacıyla işletmeciler tarafından yaratılan ya da manipüle edilen somut ve soyut çevresel uyaranlar olarak tanımlanan hizmet uzantıları son yillarda hem pazarlama hem de turizm araştırmalarında incelenen bir konudur. Alanda yapilan araştırmalarda müşterilerin fiziksel çevre ve hizmet uzantılarına duygusal ve bilişsel tepkiler verdiği ve hizmet uzantılarının müşteri tatmini ve davranışlarının en önemli belirleyicisi olduğu belirlenmiştir (Hightower, Brady ve Baker 2002; Contryman ve Jang 2006; Sim, Mak ve Jones 2006; Ryu ve Jang 2007; Namasivayam ve Mattila 2007; Lee vd. 2008; Jang ve Namkung 2009; Kim ve Moon 2009). Özellikle hedonik tüketimin merkezde olduğu alanlarda müşterilerin/turistlerin bir otel, restoran, etkinlik alanı ya da destinasyonun hizmet uzantılarına diğer müşterilerden daha fazla duyarlı oldukları ileri sürülmektedir (Wakefield ve Blodgett 1994; 1996; 1998; 1999). Bu nedenle, turizm oluşumlarında hizmet uzantılarının anlaşılması ve incelenmesinin önemi daha fazla artmaktadır. Ancak yapılan araştırmaların çoğunda atmosfer ve ambiyans gibi genel hizmet çevresine ait hizmet uzantılarına odaklanıldığı, müşteri deneyiminin şekillendirilmesinde önemli bir katkısı olan okunabilirlik boyutunun inceleme dışında bırakıldığ 1 gözlenmiştir.

Bu çalışmada deneyimsel bir hizmet uzantısı olarak sinıflandırılan "okunabilirlik"in bir turizm türü olan iş amaçlı etkinlikler kapsamında açıklanması ve boyutlarının belirlenmesi amaçlanmıştır. Okunabilirliğe ilişkin yapılan araştırmalar incelendiğinde, perakende çevrelerinde olduğu gibi turist/ katılımci-çevre etkileşiminin gerçekleştiği çevrelerde de oldukça sinırlı sayıda araştırma yapıldığı gözlenmektedir. Turizm alanyazınında Newman (1995; 2007) ile Foxall ve Hackett'in (1994) çalışmaları dışında bir turizm deneyimi ve çevresinin okunabilirliği incelenmemiştir. Ancak bilindiği üzere turizm, özünde bireylerin kendilerine yabancı çevrelere seyahatlerini içeren bir olgudur. Bu nedenle bireylerin kendilerine yabancı olan bir çevrede hareket etmelerini kolaylaştıracak, deneyimlerini zenginleştirecek okunabilirlik boyutlarının özellikle incelenmesi gerekmektedir. Bu çalışmada, iş amaçlı etkinliklerden biri olan seminerlerin deneyimsel bir hizmet uzantısı olarak okunabilirlik boyutlarının belirlenmesi ve ortaya çıkarılması amaçlanmıştır.
Hizmet uzantıları araştırmalarında genellikle fiziksel çevrenin somut unsurlarına odaklanılmakta ve bu somut unsurların oluşturduğu salt fiziksel çevrenin müşteriler üzerinde etkilerinin araştırıldığı görülmektedir. Ancak hizmet uzantıları, fiziksel çevreyi kuşatan unsurlar olmasının yanı s1ra müşteri "deneyimlerini" şekillendiren en kritik boyutlardan birini oluşturmaktadır. Bu nedenle bu araştırmada bir hizmet uzantısı olarak tanımlanan "okunabilirlik" sadece etkinliğin gerçekleştiği fiziksel çevredeki bir uyaran olarak değil, aynı zamanda etkinlik deneyiminin her boyutunda etkinlik katılımclarının duygusal ve davranışsal sonuçlarını etkileyen deneyimsel bir hizmet uzantısı olarak ele alınmıştır.

\section{ILGILI ÇALIŞMALAR}

Pazarlama alanında hizmet uzantılarına ilişkin çalışmalar Philip Kotler'in (1973) pazarlama aktivitelerinde yer alan fiziksel çevre tanımı için "atmosfer" terimini kullanmasına dayanmaktadır. Kotler (1973: 50) çalışmasında, hizmet uzantılarını "atmosfer" kavramı çerçevesinde değerlendirmiş ve atmosferi yani hizmet uzantılarını; müşterilerin satın alma olasılığını artıran, müşteride spesifik duygusal tepkilerin ortaya çıkması için satın alma çevresinin tasarımı olarak tanımlamıştır. Kotler (1973), somut ürünlerin sadece toplam tüketim paketinin bir bölümü olduğunu, ancak müşterilerin toplam ürüne tepki verdiklerini belirtmiştir. Toplam ürünün en önemli özelliklerinden biri, tüketim ya da satın almanın gerçekleştiği fiziksel çevredir. Kotler (1973: 48), fiziksel çevre atmosferinin, satın alma kararı üzerinde ürünün kendisinden çok daha etkili olduğunu, bu durumlarda "atmosfer" in birincil (temel) ürün olduğunu ifade etmiştir. Kotler' in ardından Bitner (1992: 58), "atmosfer" kavramını genişletmiş ve hizmet organizasyonlarında hem personel hem de müşteriler üzerinde etkiye sahip mekân çevresini "hizmet uzantıları" olarak tanımlamıştır. Bitner (1992: 58), hizmet uzantılarını, personelin ve müşterilerin eylemlerini (davranışlarını) geliştirmek için işletme tarafından kontrol edilebilen nesnel fiziksel faktörlerin tümü olarak tanımlamıştır. Ezeh ve Haris (2007: 61), yukarıda sıralanan hizmet uzantıları tanımlarına dayanarak hizmet uzantılarını; müşterileri yaklaşma/kaçınma davranışını sergilemeye yönelten, müşteriler üzerinde içsel tepkilere neden olan, hizmet karşılaşmasına 
ev sahipliği yapan fiziksel çevrenin tasarımı olarak tanımlamışlardır.

Hizmet uzantılarının, müşterilerin ürünleri alg1lamaları üzerinde büyük bir etkiye sahip olduğu yapılan araştırmalarla ortaya konulmuştur (Donovan ve Rossiter 1982; Turley ve Milliman 2000). Araştırmalara göre; hizmet uzantıları, ürünlerin mallardan hizmetlere ve hizmetlerden deneyimlere dönüşümüne yardımcı olmakta ve böylece ürünün değerini arttırmaktadır (Pine ve Gilmore 1999: 5). Hizmetlerin soyut doğası nedeniyle müşteri deneyimi, ürün/ürünlerin değerlendirilmesini belirleyen önemli bir faktördür. Sunulan hizmetler, tüketim öncesi denenemediği ve değerlendirilemediği için müşteriler, kalite algısı olarak deneyimsel bileşenleri, yani hizmet uzantılarını değerlendirme eğilimindedirler. Bu nedenlerden dolayı hizmetler, "deneyim" ürünleri olarak sinıflandırılmaktadır. Hizmet sektöründeki işletmeler son yıllarda artan rekabet nedeniyle işletmelerine ve destinasyonlara daha fazla turist çekmek, ürünlerini farklılaştırmak (Kotler 1973; Baker, Berry ve Parasuraman 1988; Newman 2007), markalarını ve imajlarını geliştirmek (Bonn, Joseph-Mathews, Dai, Hayes ve Cave 2009: 346) ve rekabet avantajı sağlamak amacıyla hizmet uzantılarından yararlanmaya başlamıştır.

Bütün endüstriler ve sektörler için ideal bir hizmet uzantısı kompozisyonu bulunmamaktadır (Kotler 1973). Bu nedenle farklı hizmet sektörleri için çeşitli hizmet uzantıları sınıflandırmaları yapılmıştır. Bu sınıflandırmalar incelendiğinde en çok kabul gören yaklaşımın Bitner (1992) tarafından yapılan sınıflandırma olduğu görülmektedir. Bitner (1992) hizmet uzantılarını ambiyans, mekân düzeni/işlevsellik ve işaretler/semboller/sanat eserleri olmak üzere üç boyutta sınıflandırmıştır. Ambiyans faktörleri; 1sı, 1şıklandırma, ses, müzik ve kokuyu içermektedir. Mekân düzeni ve işlevsellik boyutunda mekân düzeni, bu unsurların boyut ve biçimleri ve bunlar arasındaki uzamsal ilişkiyi, makineler, ekipman ve mobilyaların düzenlenmesini ifade ederken; işlevsellik ise hedeflerin başarılması ve performansın kolaylaştırılmasında kullanılan benzer unsurların yeteneği olarak ifade edilmektedir (Bitner 1992: 65-67; Zeithaml ve Bitner 1996: 534-536). Bitner' in sinıflandırmasının yanı sıra Baker (1987) hizmet uzantılarını, bireylerin farkındalık düzeylerinin gerisinde yer alan arka plandaki unsurlar olarak "ambiyans" faktörleri; farkında- lık düzeyinde yer alan uyaranları içeren "tasarım" faktörleri ve çevredeki insanları kapsayan "sosyal" faktörler olarak sınıflandırmıştır. Bu sınıflandırmalarda "okunabilirlik" ayrı bir boyut olarak yer almamış, ancak sınırlı da olsa çeşitli araştırmalarda "işaretleme", "yerleşim düzeni" olarak farklı boyutlar altında yer almıştır. Bu kapsamda araştırmalarda fiziksel çevrenin okunabilirliğini sağlayan unsurlar olan mekân giriş ve çıkışları (Wakefield ve Blodgett 1996), mekânın yerleşim düzeni (Wakefield, Blodgett ve Sloan 1996; Chang 2000; Countryman ve Jang 2006; Heide ve Gronhaug 2006; Ryu ve Jang 2007; Wall ve Berry 2007, Edwards ve Gustafsson 2008; Kwortnik 2008), alan dağılımı (Wakefield, Blodgett ve Sloan 1996; Ryu ve Jang 2007; Bonn, Joseph-Mathews, Dai, Hayes ve Cave 2009) ve işaretleme (Wakefield, Blodgett ve Sloan 1996; Heide ve Gronhaug 2006; Ryu ve Jang 2007; Lee, Lee, Lee ve Babin 2008; McDonnell ve Hall 2008; Bonn, JosephMathews, Dai, Hayes ve Cave 2009) farklı hizmet uzantıları boyutları altında incelenmiştir.

Pazarlama yazınında bir hizmet uzantısı boyutu olarak "okunabilirlik" ilk kez Foxall ve Hackett (1994) tarafından uluslararası bir kongre merkezinin mekânsal özelliği olarak incelenmiştir. Araştırmada kongre merkezinin okunabilirliği "yol ve yön bulma" olarak tanımladıkları tek bir boyut olarak ele alınmıştır. Okunabilirliğe ilişkin yapılan bir diğer araştırmada Newmann (2007) okunabilirlik boyutlarını tanımlamaya ve bu boyutların havaalanı ziyaretçilerinin duygusal tepkileri üzerindeki etkilerini belirlemeye çalışmıştır. Araştırmada bir havaalanının okunabilirlik boyutları "mekânsal düzenleme" ve "yol ve yön bulma" olarak isimlendirilen iki boyutta incelenmiştir. Pazarlama alanında okunabilirlik olgusuna ilişkin sınırlı sayıda araştırma olmasına rağmen çevre psikolojisi alanında okunabilirlik olgusu için kuramsal bir temel sağlanmış ve çok sayıda araştırma yapılmıştır. Okunabilirlik çevre psikolojisinde çevresel bir uyaran (Lynch 1960; Kaplan ve Kaplan 1978; 1979; 1995; Weisman 1981; Passini 1984) pazarlama ve turizm alanında ise bir hizmet uzantısı boyutu olarak tanımlanmıştır (Foxall ve Hacket 1994; Titus ve Everett 1995; Newmann 1995; Newmann 2007). Genel olarak okunabilirlik, bir çevrenin zihinde imge oluşturabilme ve tutarlı bir örüntü olarak organize edilebilme olanağına işaret etmektedir (Lynch 1960: 2). Kaplan ve Kaplan da $(1978 ; 1979 ; 1992 ; 1995)$ geliştirdikleri Tercih Matrisi Modeli'nde okunabilirliği, bireyle- 
rin mekân tercihlerinde çevresel bir uyaran olarak ele almışlar ve bireyin bir çevrede yönünü kolay bir şekilde bulabilmesi ve başlangıç noktasına kolay bir şekilde dönebilmesi için belirgin unsurlarla mekânın iyi bir şekilde yapılandırılması olarak tanımlamışlardır. Kaplan ve Kaplan'a göre belirli çevreler ve mekânlara ilişkin temel bilgi ihtiyacr bireylerin tercihlerini etkilemektedir (Kaplan ve Kaplan 1995: 58). Passini (1984: 6) ise okunabilirli$\breve{g i}$, hedeflenen bilginin anlamlandırılması ve çıkarsanması için çevrenin elverişli olması, çevresel kalite olarak tanımlamıştır. Bu tanım, çevresel okunabilirliğin müşterilerin hizmet çevresinde yönlerini/ yollarını bulmada merkezi bir rol oynadığını vurgulamaktadır (Titus ve Everett 1995: 107). Yapilan tanımlar turizm ve etkinlik deneyimi çerçevesinde düşünüldüğünde okunabilirliğin turistlerin ya da etkinlik katılımcılarının fiziksel bir çevrede yollarını bulma ve aradıkları bilgiye ulaşmalarında önemli bir rol oynadığı sonucunu ortaya çıkarmaktadır.

Okunabilirlik kavramına ilişkin ilk çalışma Lynch (1960) tarafından yapılmıştır. Lynch (1960: 2) okunabilirliği psikolojik bir yapı olarak incelemiş ve okunabilirliği çevrenin kolayca fark edilmesi ve belirli bir doku olarak organize edilme kolaylığı olarak tanımlamıştır. Lynch'e göre düzenli, okunabilir bir çevre bireyler için somut bir referans sistemi veya bilgi düzenleyicisi olabilmektedir. Çevre psikolojisi alanında farklı araştırmacıların okunabilirlik kavramını açıklamak için düzen ve açıklık (Lynch 1960; Nasar 1994, 2000; Oostendorp ve Berlyne 1978; Deng ve Poole 2012), yol ve yön bulma (Lynch 1960; Weismann 1981; Passini 1988), işaretlendirme/araçlar (Lynch 1960; Newmann 1995, 2000; Doğu ve Erkip 2000) gibi çeşitli boyutları (kavramları) incelediği görülmüştür. Benzer şekilde Köseoğlu (2012), alanyazında okunabilirlik kavramına ilişkin olarak düzen, basitlik, tutarlılık, anlaşılabilirlik ve algılanabilirlik gibi farklı boyutların kullanıldığının görüldüğünü ve tüm bu kavramların, mekânın yapısından doğan özellikleri ifade ettiğini belirtmiştir (Köseoğlu 2012). Aşağıda, alanyazın incelemesi sonucu belirlenen okunabilirlik kavramının alt boyutları açıklanmıştır.

\section{Düzen ve Açıklık}

Lynch, çalışmasında okunabilirlik kavramını mekânsal organizasyon olarak ele almış ve "düzen" (order) boyutunu bu kavramı açıklamak ama- cıyla kullanmıştır. Lynch'in yanı sıra Nasar (1984; 2000) okunabilirlik boyutunu incelemek için "düzen" ve "açıklık" kavramlarını kullanmıştır. Nasar (1984), bir çevrenin organizasyonu ile ilişkili olan "düzen" kavramını açılarken uyum, okunabilirlik ve açıklık unsurlarını bir arada kullanmış ve bu kavramın çevrenin organizasyonu ile ilişkili olduğunu belirtmiştir. Bu kapsamda düzen, bir çevrenin ya da mekânın bölümleri arasındaki dengeli ilişkilerin niteliği ve derecesi olarak tanımlanmaktadır (Nasar 2000). Açıklık ise bir çevrenin fark edilme süreci ile yakından ilişkili çeşitli unsurların tanımlanabilirliğini yansıtmaktadır (Deng ve Poole 2012). Nasar (1984), Oostendorp ve Berlyne (1978) tarafından tanımlanan açıklık/düzenlilik faktörlerine benzer şekilde "düzen" boyutu, uygunluk, benzeşim ve açıklık kapsamı/ölçüsü gibi çevrenin organizasyonu ile ilişkilidir. Uyum, uygunluk ve benzeşim kavramları çevredeki harmoniyi geliştirebilecek unsurların nasıl bir araya getirildiği ile ilişkili iken okunabilirlik kavramı tüm bu boyutları kapsayacak şekilde, mekânın çeşitli bölümlerinin uyumlu bir örüntü içerisinde organize edilebilmesi ve tanınabilmesidir (Lynch 1960).

\section{Yol ve Yön Bulma}

Okunabilirlik kavramının incelenmesinde ele al1nan bir diğer boyut ise yol ve yön bulmadır (Lynch 1960; Weisman 1981; Passini 1988; Newman 2007). Temelde Lynch (1960), okunabilirliği, bireyin bir çevrede yönünü kolay bir şekilde bulabilmesi ve başlangıç noktasına kolay bir şekilde dönebilmesi için belirgin unsurlarla mekânın iyi bir şekilde yapılandırılması olarak tanımlamıştır. Benzer şekilde Weisman (1981) okunabilirliği bireyin fiziksel çevrede yönünü kolaylaştırıcı bir öge, çevre kalitesi olarak tanımlamıştır. Passini ise (1988) okunabilirliği, çevrenin bilgi kalitesinin bir mekânda ya da fiziksel çevrede yön ve yol bulmayı kolaylaştırması olarak tanımlamıştır. Bu çerçevede düzen ve açıklık boyutlarının yanı sıra araştırmacıların yol ve yön bulma boyutunu bir çevrenin okunabilirliğini sağlayan bir yapı olarak ele aldıkları görülmektedir.

\section{İşaretlendirme ve Araçlar}

Bir çevrede kullanılan işaretlendirme ve araçlar bir mekânda yol ve yön bulmayı sağlayan dolayısıyla mekânın okunabilirliğini destekleyen unsurlar olarak ele alınmaktadır. Haritalar, işaretler ve diğer 
görsel organlar deneyimlenmemiş bir mekânda yol ve yön bulma davranışı için gerekli unsurlar olarak tanımlanmaktadır (Doğu ve Erkip 2000). Bunun yanı sıra Lynch (1960) işaret ögelerini çevre/mekân imgesinin oluşturulmasında, çevrenin tanımlanmasında ve çıarsanmasında temel unsurlar olarak ele almaktadır. Ayrıca mekânda kullanılan işaretlerin düzeni ve belirginliği, çevre ya da mekân içerisinde yön ve yollarını bulmasında bireylere yardımcı olabilmektedir. Bu çerçevede mekânda kullanılan işaretler, bireylerin yol ve yön bulmalarında dolayısıyla mekânın okunabilirliğinin sağlanmasında önemli bir etken olarak incelenmektedir. Havaalanlarının okunabilirliğine ilişkin çalışmasinda Newmann $(1995 ; 2007)$ okunabilirliğin temel unsurlarından çevresel işaretlerin kullanımının, havaalanı ziyaretçilerinin çevrede kaybolmalarını engelleyeceğini (Newmann 1995), ziyaretçilerin keşfetme ya da arama gibi davranışlarını desteklediğini ve yeni bir çevrede alışılmamışlık duygusunu azalttığını, bireylerin yeni bir çevreye hızlı ve kolay bir şekilde adapte olmalarına yardımcı olduğunu belirtmiştir (Newmann 2007: 19).

Çevre psikolojisi alanında okunabilirliği açıklamak için farklı boyutların kullanıldığı görülmektedir: Basit, tutarlı, anlaşılabilir, algılanabilir gibi. Tüm bu kavramlar, mekânın yapısından doğan özellikleri ifade etmektedir. Mekânsal okunabilirliği bu kavramlar üzerinden ölçebilmek için mekânın boyutları arasında bir ayrıştırma yapmak gerekmektedir (Köseoğlu 2012). Bu nedenle bu araştırmada da bir etkinliğin okunabilirliğini ölçebilmek amacıyla etkinliğin boyutları arasında bir ayrıştırmaya gidilmiş ve okunabilirlik boyutu etkinliğin düzenlendiği destinasyon, otel ve seminer salonları olan fiziksel mekanlar ile etkinliğin web sitesi gibi sanal mekanlar çerçevesinde değerlendirmeye alınmıştır. Ayrıca alanda yapılan çalışmalar incelendiğinde okunabilirlik boyutunun daha çok fiziksel mekânlar ile sınırlandırılmış olduğu ancak son yıllarda yapılan çalışmalara sanal çevrelerin de eklendiği görülmüştür (Deng ve Poole 2012). Bu nedenle çalışmada sanal bir çevre olarak etkinlik web sitesi de etkinlik mekânı olarak değerlendirmeye alınmıştır.

\section{ANAKÜTLE VE ÖRNEKLEM}

Çalışmanın ana kütlesini, Antalya'da düzenlenen VII. Araştırma Yöntemleri Semineri'ne katılan ka- tılımcılar oluşturmaktadır. Araştırma yöntemleri seminerleri, 2002 yılından beri akademisyenlerin ve lisansüstü öğrencilerin araştırma yöntem ve teknikleri hakkındaki bilgi ve deneyimlerinin geliştirilmesi amacıyla düzenlenmektedir. Çalışmada tam sayım yapılmış, 230 seminer katılımcısı araştırma kapsamına alınmıştır.

\section{VERI TOPLAMA YÖNTEMI}

Bu çalışma, bir kavramı oluşturan boyutların ortaya çıkarılmasında Churchill (1979) ve diğer araştırmacilar (Anderson ve Gerbing 1982; 1988; Arnold ve Reynolds 2003) tarafından önerildiği gibi kuramsal ve alan araştırması olmak üzere iki aşamada gerçekleştirilmiştir. Seminer etkinliklerinin, okunabilirlik boyutunu oluşturan temel yapıların belirlenebilmesi ve tanımlanabilmesi amaciyla öncelikle, çevre psikolojisi ve pazarlama dallarında kapsamlı bir alan yazın taraması yapılmıştır. Yazın taraması kapsamında, çevresel bir uyaran olarak okunabilirliğin incelendiği çevre psikolojisi ve çevre estetiği (Lynch 1960; Kaplan ve Kaplan 1975; 1978; 1979; 1987; 1989; 1992; 1995; Weisman 1981; Passini 1984) pazarlama ve turizm (Foxall ve Hacket 1994; Titus ve Everett 1995; Newmann 1995; Newmann 2007) alanları incelenmiştir. Yazın taraması sonucunda etkinlik öncesi ve etkinlik süresince bir etkinliğin okunabilirlik boyutlarını oluşturan unsurlar "Organizasyonel Açıklık" (Lynch 1960; Nasar 1998; 2000; Kaplan ve Kaplan 1995), "Yol ve yön bulma" (Lynch 1960; Foxall ve Hacket 1994; Newman 2007), "İşaretlendirme" (Lynch 1960; Newman 2007), “Mekânsal Düzenleme" (Lynch 1960; Nasar 1984; 2000), "Bilgilendirme" (Kaplan ve Kaplan 1995) ve "Araçlar" (Lynch 1960; Newman 2007) olarak belirlenmiştir. Belirlenen bu boyutları oluşturan ifadeler, ilgili araştırmalardan yararlanılarak elde edilmiştir. İzlenen bu adımlar sonucunda 32 maddeden oluşan bir ölçek elde edilmiştir. Ölçeğin kapsam geçerliği için üç kişiden oluşan grubun görüşlerine başvurularak akademisyenlerden ölçek maddelerinin çalışmanın amacına uygunluğunu ve anlaşılırlığını değerlendirmeleri istenmiş; bu aşamada iki madde ölçekten çıkarılmıştır.

Yukarıda açıklanan aşamaların sonucunda oluşturulan soru formunda, etkinliğin okunabilirlik boyutlarının belirlenmesi amaciyla 30 adet ifade ve katılımcıların demografik özelliklerine yönelik 
üç adet demografik soru bulunmaktadır. Katılımclların demografik özelliklerine yönelik ölçümlerin dışındaki sorular, 7'li Likert ölçeğinde yapılandırllarak "7-Kesinlikle Katıllyorum" seçeneğinden "1-Kesinlikle Katılmıyorum" seçeneğine doğru belirli bir aralıkla sıralanmıştır. Ayrıca soru formuna, yöneltilen ifadeler hakkında bir görüşü olmayan katılımcılar için "Fikrim Yok" sütunu eklenmiştir ve "Fikrim Yok" olarak belirtilen maddeler veri girişinde kayıp veri olarak girilmiştir. Demografik özelliklere ilişkin sorular ise nominal ölçekte ve yalnızca tek seçenek işaretlenecek şekilde tasarlanmiştır.

Çalışmanın verileri yüz yüze uygulanan anket yolu ile derlenmiştir. Seminerin son günü, anketler 230 seminer katılımcısına dağıtılmış, dağıtılan anketlerden 137 kullanılabilir anket değerlendirilmeye alınmıştır.

\section{VERILERIN ANALIZE HAZIRLANMASI}

Verilerin analize hazırlanması aşamasında, öncelikle kayıp verilerin çözümüne çalışılmıştır. Araştırmalarda yer alan ve kayıp değer veya değerleri içeren birimler, bir bilgi yokluğunu temsil etmektedirler, dolayısıyla bir bilgi kaybına neden olmaktadirlar. Standart istatistiksel yöntemler ve paket programları tam bilgi durumu için düzenlenmişlerdir. Söz konusu analizler kayıp değer içeren birimlere uygulandıklarında yanlı tahminlere sebebiyet vereceklerdir. Bu nedenle çalışmada öncelikle kayıp veri problemi ele alınmış, bu amaçla çoklu atıf yöntemi (Multiple Imputation-MI) kullanılmıştır. Çoklu atıf yöntemi (MI), kayıp değerlerin yerine $m$ tekrar sayısı ve $m>1$ olmak üzere simüle edilmiş versiyonlarının kullanıldığ 1 bir Monte Carlo tekniğidir. Çoklu atıf yöntemi, analizde yer alan değişkenlerin normalliği ihlal ettiği durumlarda iyi sonuçlar verdiği; liste bazında veri bozma, çiftler bazında veri bozma ve yerine ortalamayı koyma yöntemlerinden daha avantajlı olarak belirtildiği için çalışmada kullanılmıştır (Oğuzlar 2001).

Kayıp veri probleminin yanı sıra açılayıcı ve doğrulayıcı faktör analizinde kullanılacak tekniklerin belirlenmesi amacıyla verilerin dağılımları incelenmiştir. Bu amaçla, grafiksel yaklaşımdan ve verilere ait çarpıklık (skewness) ve basıklık (kurtosis) değerlerinden yararlanılmıştır. Söz konusu istatistikler için kritik değerler basıklık için \pm 2 , çarpıklık için ise \pm 2 olarak ifade edilmektedir (Ha- ir vd. 1998). Araştırma verilerine ait değişkenlerin basıklık ve çarpıklık değerleri belirtilen aralıklarda bulunmuştur. Bu nedenle, değişkenlere ilişkin verilerin normal dağ 1 lım sergilediği kabul edilmiştir ve açıklayıcı faktör analizinde temel bileşenler analizi ve varimax tekniği kullanılmıştır. Yapısal eşitlik modellemesinde yaygın olarak kullanılan tahmin metotları çok değişkenli normallik varsayımını temel aldığından araştırmada doğrulayıcı faktör analizine geçilmeden önce çok değişkenli normallik analizi gerçekleştirilmiştir. Bu nedenle çok değişkenli normallik testi için Mardia'nın çok değişkenli normallik testi kullanılmıştır.

\section{ANALIZ VE BULGULAR}

VII. Araştırma Yöntemleri Semineri'ne katılan 137 katılımcıdan elde edilen verilerin analizi ile ilgili hesaplamalarda SPSS for Windows 17.0 ve Lisrel 8.8 paket programlarından yararlanılmıştır. Değerlendirmede katılımcıların tanımlayıcı verileri frekans analizi ile incelenmiş, elde edilen bulgular frekans dağılım tablosunda gösterilmiştir. Seminerin okunabilirlik boyutlarının belirlenebilmesi için öncelikle verilere açıklayıcı faktör analizi uygulanmış, daha sonra açıklayıcı faktör analizi ile elde edilen ölçeğin tek boyutluluğunu incelemek amacıyla doğrulayıcı faktör analizi yapılmıştır.

\section{Tanımlayıcı Bulgular}

Tablo 1'de VII. Araştırma Yöntemleri Semineri'nin katılımcılarına ilişkin tanımlayıcı bilgiler yer almaktadır. Araştırmaya dâhil olan seminer katılımcilarının \%67,9'unun kadın ve \%32,1'inin erkek olduğu; yaş grupları incelendiğinde 26-31 (\%40,2), 22-37 (\%23,6) ve 38-43 $(\% 15,7)$ yaş aralığında oldukları belirlenmiştir. Akademik unvanlar incelendiğinde ise seminer katılımcilarının \%33,3'ünün araştırma görevlisi, \%24,4'ünün yardımcı doçent ve $\% 15,4^{\prime}$ ünün öğretim görevlisi olduğu tespit edilmiştir.

\section{Açıklayıcı ve Doğrulayıcı Faktör Analizi}

Seminerlerin okunabilirlik boyutlarının ve ölçeğin yapı geçerliğinin belirlenebilmesi amacıyla öncelikle açılayıcı faktör analizinden (AFA) daha sonra da belirlenen boyutların doğrulanmasında ve ölçüm modelinin geçerliliğini ve güvenilirliğini test etmede birinci düzey doğrulayıcı faktör anali- 
Tablo 1. Seminer Katılımcılarına Ait Tanımlayıcı Bilgiler

\begin{tabular}{lrrlrr}
\hline Cinsiyet & $n$ & $\%$ & Görev & $n$ & $\%$ \\
\hline Kadın & 91 & 67,9 & Araştırma Görevlisi & 41 & 33,3 \\
\hline Erkek & 43 & 32,1 & Yardımcı Doçent & 30 & 24,4 \\
\hline Toplam & 134 & 100,0 & Öğretim Görevlisi & 19 & 15,4 \\
\hline Yaş & & & Yüksek Lisans/Doktora Öğrencisi & 17 & 11,4 \\
\hline $20-25$ & 16 & 12,6 & Doçent & 6 & 4,9 \\
\hline $26-31$ & 51 & 40,2 & Uzman & 6 & 4,9 \\
\hline $22-37$ & 30 & 23,6 & Profesör & 2 & 1,6 \\
\hline $38-43$ & 20 & 15,7 & Öğretmen & 2 & 1,6 \\
\hline $44-49$ & 5 & 3,9 & Toplam & 123 & 100,0 \\
\hline $50-55$ & 5 & 3,9 & & &
\end{tabular}

zinden (One Order Confirmatory Factor Analysis) yararlanılmıştır.

Çalışmada açıklayıcı faktör analizine başlamadan önce, örneklem büyüklüğünün faktör analizine uygunluğunu gösteren KMO (Kaiser-Meyer-Olkin) değerleri hesaplanmış ve Seminer Okunabilirlik ölçeği için ,865 olarak bulunmuştur. KMO değerlerinin 0,50 'den büyük olması örneklemin faktör analizi için yeterli olduğunu gösterdiğinden bu veriler üzerinden faktör analizi yapılabileceği sonucuna varılmıştır. İkinci olarak her bir ölçek için değişkenler arasındaki ilişkiyi gösteren Bartlett's Sphericity testi incelendiğinde (Okunabilirlik ölçeği için $\chi^{\wedge} 2=2861,020 ; \varrho=, 0000$ ) elde edilen verilerin anlamlı farklılık gösterdiği ve faktör analizi yapmaya uygun olduğu belirlenmiştir.

Çalışmada belirlenen 30 madde ile seminerin okunabilirlik boyutlarını tanımlamak için faktör analizi yapılmıştır. Teorik açıdan anlamlı yapıların ortaya çıkması için $0,40^{\prime}$ tan daha küçük faktör yük değerine sahip maddeler elenmiştir (Hair vd. 1998: 111). Madde eleme süresince ölçekteki madde sayısı 30'dan 28 maddeye indirilmiştir. AFA analizi sonucu toplam varyansın $\% 72,29^{\prime}$ unu açılayan altı boyut tanımlanmıştır. Tablo 2'de görüldüğü gibi AFA sonucu seminerin okunabilirliğini kapsayan altı boyut (a) Organizasyonel Açılklk, (b) Yol ve Yön Bulma, (c) İşaretlendirme, (d) Mekânsal Düzenleme, (e) Bilgilendirme ve (f) Araçlar olarak isimlendirilmiştir. Bilindiği üzere ölçeklerin güvenilirliğinin (içsel tutarlılığının) değerlendirilmesinde en yaygin metot olan Cronbach Alpha testinde katsayının 0,70'ten büyük olması tercih edilir (Hair vd. 1998: 118). Bu araştırmada belirlenen faktörlerin Cronbach Alpha katsayıları ,94 ile ,77 arasında değişmektedir. Bu sonuç, ölçeğin içsel tutarlılığ1nın yüksek olduğunu ve yapıya ait alt boyutların güvenilir olduğunu, ölçülmek istenilen özelliğin büyük olasılıkla doğru biçimde ölçüldüğünü göstermektedir.

Açıklayıcı faktör analizi ile elde edilen ölçeğin tek boyutluluğunu incelemek amaciyla birinci düzey doğrulayıcı faktör analizi (DFA) uygulanmıştır. Analizde LISREL 8.80 paket programı kullanılarak girdi verisi olarak kovaryans matrisi ve maksimum olabilirlik kestirimi kullanılmıştır. Analizin ilk aşamasında program tarafından gözlenen değişkenlere ilişkin düzeltmeler önerilmiştir. Bu çerçevede Şekil 1'de görülen gözlenen değişkenlerin hata katsayılarının ilişkili olduğu belirlenmiştir. Bilindiği üzere değişkenlerin hataları birbiriyle ilişkili olduğunda, her bir gizil değişkenin kuramsal yapısı bozulmakta ve ölçüm modelini oluşturan gizil değişkenlerin birbirinden bağımsız olmadığı sonucu ortaya çıkmaktadır (Yılmaz ve Çelik 2009: 116). Bu nedenle çalışmada hata katsayılarının ilişkili olduğu görülen gözlenen değişkenler arasında modifikasyon yapılmış ve daha sonra analiz tekrarlanmıştır. Tekrarlanan analiz sonucunda ölçeğe ilişkin elde edilen uyum değerleri Tablo 3 'te yer almaktadır. Ölçeğin DFA analiz sonuçlarına göre $\chi^{2}=617,77$ ve $\mathrm{df}=329$ olarak gerçekleşmiştir. Bu sonuçlar ölçek için uygun ve kabul edilebilir bir durumu ifade ederken, $\chi^{2} / \mathrm{df}<2(617,77 / 329=1,8)$ 
Tablo 2. Seminer Okunabilirlik Ölçeği Açıklayıcı Faktör Analizi

\begin{tabular}{|c|c|c|c|c|}
\hline & $\begin{array}{r}\text { Faktör Yük } \\
\text { Değeri }\end{array}$ & Özdeğer & $\begin{array}{r}\text { Açıklanan } \\
\text { Varyans }\end{array}$ & $\begin{array}{r}\text { Cronbach } \\
\text { Alpha }\end{array}$ \\
\hline Faktör 1 Organizasyonel Açıklık & & 9,36 & 35,84 & ,94 \\
\hline Seminer web sitesi, ödeme hakkında yeterli bilgi sağlamaktadır & ,871 & & & \\
\hline Seminer web sitesinin içeriği anlaşılabilirdir & ,870 & & & \\
\hline Seminer web sitesi, seminer başvuru uygulamaları hakkında anlaşılabilir bilgi sağlamaktadır & 821 & & & \\
\hline Seminer web sitesine kolayca ulaşılabilmektedir & ,817 & & & \\
\hline Seminer web sitesi, seminerin düzenlendiği otel hakkında yeterli bilgi sağlamaktadır & ,787 & & & \\
\hline Seminer web sitesinin içeriği iyi organize edilmiştir & ,768 & & & \\
\hline Seminer web sitesi, düzenlenen seminer hakkında yeterli bilgi sağlamaktadır & ,664 & & & \\
\hline Seminer web sitesi, seminere ilişkin bütün bilgi intiyacımı karşılamaktadır & ,660 & & & \\
\hline Seminer web sitesi kolay okunabilmektedir &, 505 & & & \\
\hline Faktör 2 Yol Ve Yön Bulma & & 4,49 & 12,45 & 82 \\
\hline Otelin mimarisi yönümü ve yolumu bulmama yardımcı olmaktadır & ,829 & & & \\
\hline Otelin giriş ve çıkışları kolayca bulunabilmektedir &, 710 & & & \\
\hline Otel koridorlarında kolayca hareket edilebilmektedir & ,672 & & & \\
\hline Otelin dinlenme alanları yeterli büyüklüktedir & ,653 & & & \\
\hline Otele kolay ulaşılabilmektedir & ,652 & & & \\
\hline Faktör 3 Işaretlendirme & & 2,14 & 8,40 & ,85 \\
\hline Antalya'daki trafik işaretleri dikkat çekecek şekilde düzenlenmiştir & ,879 & & & \\
\hline Antalya'daki yönlendirme işaretleri kolay anlaşllabilmektedir & ,854 & & & \\
\hline Antalya'daki tabelalar kolay anlaşılabilmektedir & 813 & & & \\
\hline Antalya'daki bilgilendirme işaretleri dikkat çekecek şekilde düzenlenmiştir &, 587 & & & \\
\hline Faktör 4 Mekânsal Düzenleme & & 1,54 & 6,55 & ,86 \\
\hline Seminer salonlarının isimleri kolay hatırlanabilir niteliktedir & ,852 & & & \\
\hline Salonlar üzerindeki bilgilendirme notları yeterli bilgi sağlamaktadır & ,840 & & & \\
\hline Seminer salonundaki yönlendirme işaretleri kolay anlaşılmaktadır &, 775 & & & \\
\hline Seminer salonlarının isimleri kolayca okunabilmektedir &, 734 & & & \\
\hline Faktör 5 Bilgilendirme & & 1,34 & 4,88 & ,77 \\
\hline Seminer programı, eğitimler hakkında yeterli bilgi sağlamaktadır &, 747 & & & \\
\hline Seminer programı kolayca anlaşılabilir şekilde düzenlenmiştir & ,681 & & & \\
\hline Seminer programı, sunumların yapılacağı salonlar hakkında yeterli bilgi sağlamaktadır & ,648 & & & \\
\hline Faktör 6 Araçlar & & 1,04 & 4,16 & ,81 \\
\hline Antalya haritası kolaylıkla anlaşılabilmektedir & ,819 & & & \\
\hline Antalya haritası yolumu bulmamda yardımcı olabilecek içeriktedir &, 785 & & & \\
\hline Antalya haritasına internetten kolayca ulaşılabilmektedir & ,710 & & & \\
\hline \multicolumn{5}{|l|}{ Toplam Açıklanan Varyans $=\% 72,28$} \\
\hline $\mathrm{KMO}($ Kaiser-Meyer-Olkin) $=\quad, 865$ & & & & \\
\hline Barlett's Test of Sphericity $X^{2}=2861,020 ; \rho=0,0000$ & & & & \\
\hline
\end{tabular}


olarak bulunmuştur ve bu bulgu ölçeğin istatistiksel olarak anlamlı olduğunu göstermektedir. Çalışmada ölçek için elde edilen RMSEA (Yaklaşık Hataların Ortalama Karekökü) değerinin 0,10'dan küçük olması (RMSEA=0,08) ölçeğe ilişkin modelin yeterli bir uyum gösterdiğini açılamaktadır (Schermelleh-Engel vd. 2003: 36). Ölçeğe ait $\chi^{\wedge} 2 /$ df ve RMSEA değerleri dışında DFA ile kurulan modelin verilere uyumunun değerlendirilmesinde çeşitli uyum indeksleri de incelenmiş̧ir. Tablo 3'te görüldüğü üzere ölçeğe ait uyum indeksleri istenilen düzeylerde gerçekleşmiştir. Buradan hareketle, okunabilirlik ölçeğinin analizde kullanılan ampirik veri ile tutarlı ve istatistiksel olarak geçerli olduğu anlaşılmaktadır.

Bilindiği üzere DFA'da bir ölçeğin geçerliğinin ve güvenirliğinin sınanmasında uyum iyiliği indekslerinin yanı sıra elde edilen standardize edilmiş değerleri (CSL), t-değerleri, faktörlerin birleşik yap1 güvenirlikleri (CR) ve açıklanan varyanslarının da (AVE) incelenmesi gerekmektedir. Tablo 4'te gösterildiği gibi ölçekte yer alan ifadelere ait standardize edilmiş değerlerin , 45 üzerinde olduğu ve bütün t-değerlerinin 1,96'nın üzerinde olduğu, başka bir

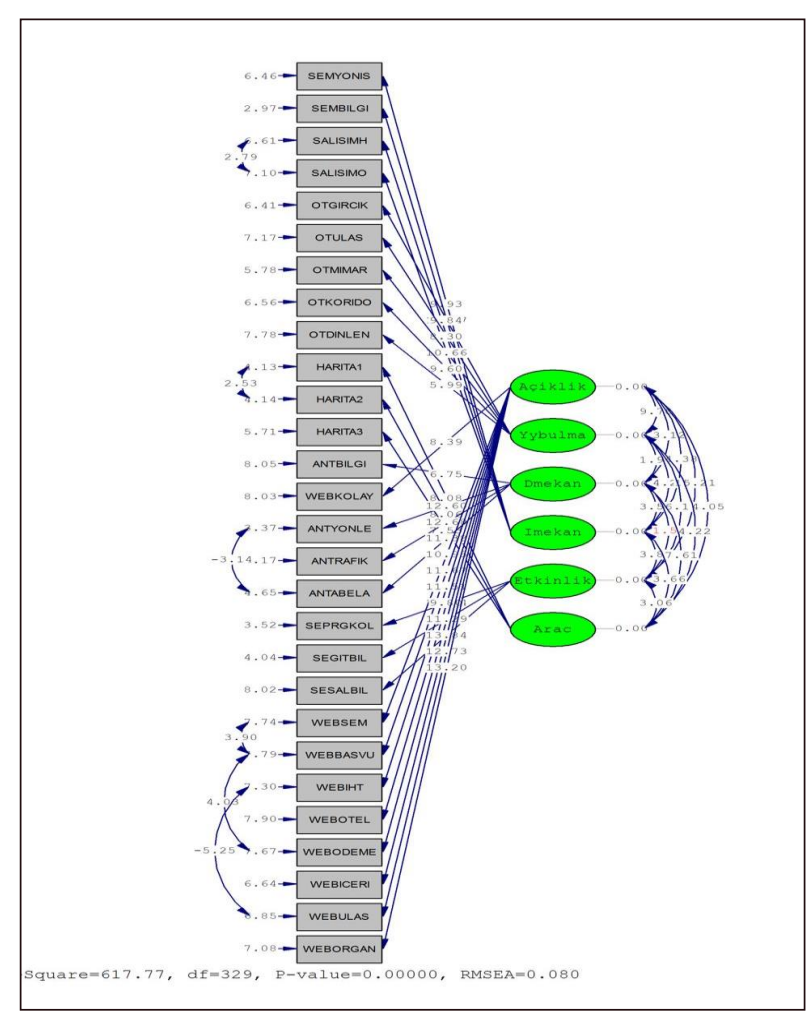

Şekil 1. Okunabilirlik Ölçeği DFA Analizi
Tablo 3. Uyum İndekslerine Ait Standart ve Ulaşılan Uyum Değerleri

\begin{tabular}{lcr}
\hline $\begin{array}{l}\text { Uyum } \\
\text { Indeksleri }\end{array}$ & $\begin{array}{l}\text { Standart } \\
\text { Değerler }\end{array}$ & $\begin{array}{r}\text { Ulaşılan } \\
\text { Değerler }\end{array}$ \\
\hline $\mathrm{X}^{2 / \mathrm{df}}$ & $<2$ & 1,8 \\
\hline $\mathrm{RMSEA}$ & $<0,10$ & 0,08 \\
\hline $\mathrm{NFI}$ & $\leq 0,90$ & 0,91 \\
\hline $\mathrm{NNFI}$ & $\leq 0,90$ & 0,94 \\
\hline $\mathrm{PNFI}$ & $\leq 0,90$ & 0,90 \\
\hline $\mathrm{CFI}$ & $\leq 0,90$ & 0,95 \\
\hline IFI & $\leq 0,90$ & 0,95 \\
\hline GFI & $\leq 0,90$ & 0,92 \\
\hline AGFI & $\leq 0,90$ & 0,91 \\
\hline SRMR & $\leq 0,10$ & 0,076 \\
\hline
\end{tabular}

deyişle bütün parametrelerin istatistiksel olarak anlamlı olduğu belirlenmiştir. Ölçeğin güvenirliğinin değerlendirilmesinde ise birleşik güvenirlik ve her bir yapı tarafından açıklanan varyans olmak üzere iki tür güvenirlik testi kullanılmıştır. Birleşik güvenilirlik Alpha katsayısı ile benzerdir ancak Alpha katsayısı tek boyutluluğu değerlendirmek yerine ölçeğin tek boyutlu olduğunu varsaymaktadır. Birleşik güvenirlik ise bir faktördeki göstergelerin içsel tutarlıklarını göstermektedir ve kabul edilebilir güvenilirlik oranı , $70^{\prime}$ tir (Hair vd. 1998: 611-612).

Yukarıda açıklandığı gibi ölçeğin güvenirliğinin değerlendirilmesinde hesaplanan bir diğer katsayı ise ortalama açılanan varyanstır (avarege variance extracted). Ortalama açıklanan varyansın ,50'den fazla olması gerektiği ifade edilmektedir. Bu değer gözlenen değişkenlerde örtük değişken tarafından açılanan ortalama varyansı verir (Hair vd. 1998: 612). Tablo 4 incelendiğinde ölçekteki faktörlerin birleşik yapı güvenirliklerinin belirtilen ,70 düzeyini aştığ1 $(, 80-, 94)$; faktörlerin ortalama açıklanan varyanslarının ,50'yi aştığ sadece "yol ve yön bulma" faktörünün ,50'ye yakın bir değer aldığ $1(44)$ görülmektedir. Elde edilen bulgulara dayanarak okunabilirlik ölçeğini oluşturan boyutların içsel tutarlılıklarının ve yapıyı açıklama güçlerinin yeterli olduğu doğrulanmaktadır.

\section{SONUÇ VE ÖNERILER}

Bu çalışmada iş amaçlı etkinliklerden biri olan seminerlerin okunabilirlik boyutlarını oluşturan un- 
Tablo 4. Doğrulayıcı Faktör Analizi

\begin{tabular}{|c|c|c|c|c|c|}
\hline & CSL & t-değeri & $R^{2}$ & $C R$ & $A V E$ \\
\hline Organizasyonel Açıklık & & & &, 94 & ,66 \\
\hline Seminer web sitesi, ödeme hakkında yeterli bilgi sağlamaktadır & ,80 & 11,29 & 0,65 & & \\
\hline Seminer web sitesinin içeriği anlaşılabilirdir & ,91 & 13,84 & 0,83 & & \\
\hline Seminer web sitesi, seminer başvuru uygulamaları hakkında anlaşılabilir bilgi sağlamaktadır & , 82 & 11,67 & 0,68 & & \\
\hline Seminer web sitesine kolayca ulaşılabilmektedir & ,87 & 12,73 & 0,76 & & \\
\hline Seminer web sitesi, seminerin düzenlendiği otel hakkında yeterli bilgi sağlamaktadır & ,73 & 9,80 & 0,53 & & \\
\hline Seminer web sitesinin içeriği iyi organize edilmiştir & 89 & 13,20 & 0,79 & & \\
\hline Seminer web sitesi, düzenlenen seminer hakkında yeterli bilgi sağlamaktadır &, 79 & 10,95 & 0,62 & & \\
\hline Seminer web sitesi, seminere ilişkin bütün bilgi intiyacımı karşılamaktadır & 82 & 11,51 & 0,67 & & \\
\hline Seminer web sitesi kolay okunabilmektedir & ,65 & 8,39 & 0,42 & & \\
\hline Yön ve Yol Bulma & & & & ,82 & ,44 \\
\hline Otelin mimarisi yönümü ve yolumu bulmama yardımcı olmaktadır & 80 & 10,66 & 0,65 & & \\
\hline Otelin giriş ve çıkışları kolayca bulunabilmektedir & ,76 & 9,84 & 0,58 & & \\
\hline Otel koridorlarında kolayca hareket edilebilmektedir & ,75 & 9,60 & 0,56 & & \\
\hline Otelin dinlenme alanları yeterli büyüklüktedir &, 51 & 5,99 & 0,26 & & \\
\hline Otele kolay ulaşılabilmektedir & ,67 & 8,30 & 0,45 & & \\
\hline Işaretlendirme & & & & 88 & 65 \\
\hline Antalya'daki trafik işaretleri dikkat çekecek şekilde düzenlenmiştir & 89 & 12,68 & 0,80 & & \\
\hline Antalya'daki yönlendirme işaretleri kolay anlaşılabilmektedir & 90 & 12,60 & 0,81 & & \\
\hline Antalya'daki tabelalar kolay anlaşılabilmektedir & ,85 & 11,38 & 0,72 & & \\
\hline Antalya'daki bilgilendirme işaretleri dikkat çekecek şekilde düzenlenmiştir &, 55 & 6,75 & 0,30 & & \\
\hline Mekânsal Düzenleme & & & & ,86 & ,62 \\
\hline Seminer salonlarının isimleri kolay hatırlanabilir niteliktedir & ,74 & 9,48 & 0,55 & & \\
\hline Salonlar üzerindeki bilgilendirme notları yeterli bilgi sağlamaktadır & ,91 & 12,57 & 0,83 & & \\
\hline Seminer salonundaki yönlendirme işaretleri kolay anlaşılmaktadır & ,76 & 9,93 & 0,58 & & \\
\hline Seminer salonlarının isimleri kolayca okunabilmektedir & ,68 & 8,39 & 0,46 & & \\
\hline Bilgilendirme & & & & 80 & ,60 \\
\hline Seminer programı, eğitimler hakkında yeterli bilgi sağlamaktadır & ,90 & 12,73 & 0,80 & & \\
\hline Seminer programı kolayca anlaşılabilir şekilde düzenlenmiştir & ,91 & 13,04 & 0,83 & & \\
\hline Seminer programı, sunumların yapılacağı salonlar hakkında yeterli bilgi sağlamaktadır & ,47 & 5,58 & 0,22 & & \\
\hline Araçlar & & & & ,82 & ,62 \\
\hline Antalya haritası kolaylıkla anlaşılabilmektedir & ,76 & 8,08 & 0,57 & & \\
\hline Antalya haritası yolumu bulmamda yardımcı olabilecek içeriktedir & ,76 & 8,06 & 0,57 & & \\
\hline Antalya haritasına internetten kolayca ulaşılabilmektedir & ,68 & 7,53 & 0,46 & & \\
\hline
\end{tabular}

surların neler olduğu araştırılmıştır. Bu nedenle, çalışmanın uygulaması iş amaçlı bir etkinlik olan seminer katılımcıları üzerinde gerçekleştirilmiştir.

$\mathrm{Bu}$ çalışma, pazarlama ve çevre psikolojisi alanlarında incelenen hizmet uzantıları ve okunabilir- lik ile ilgili kuram ve çalışmalara dayanmaktadır. Çalışmada geliştirilen ölçek ile özellikle çevre psikolojisinde daha çok kavramsal olarak açıklanan ve nitel olarak ölçülen okunabilirlik yapısının nicel ölçümüne olanak sağlanmaktadır. Hizmet uzantı- 
larının ve okunabilirliğin sınanmasında bina çevresine odaklanan çalışmalarından farklı olarak bu çalışmada okunabilirlik boyutu, salt bir fiziksel mekan yerine otel ve destinasyon gibi çoklu mekanları içerisinde barındıran etkinlik deneyimi temel alınarak belirlenmiştir. Bilindiği üzere, bir etkinlik deneyimi sadece etkinlik tarihi süresince gerçekleşen deneyimleri değil etkinlik öncesi deneyimleri de kapsamaktadır. Bu nedenle, çalışmada etkinliğin okunabilirlik boyutu katılımcıların etkinlik öncesi deneyimlerinin bir parçası olan ve etkinlik süresince yaşayacakları deneyimlerine ilişkin beklentilerinin oluşmasında önemli rol oynayan sanal bir etkinlik çevresi olarak web sitesini de içermektedir. Bu çerçeveden bakıldığında, diğer çalışmalardan farklı olarak bu çalışmada sadece fiziksel mekânın okunabilirliği değil aynı zamanda etkinlik deneyiminin bir parçası olarak tanımlanabilecek sanal web sitesinin okunabilirliği de incelenmiştir. Pazarlama alanında yapılan çalışmalarda okunabilirlik boyutu tek bir yapı olarak ele alınmış ancak bu yapı içerisinde yer alan boyutlar göz ardı edilmiştir. Bu çalışmada okunabilirlik yapısının temelinde yatan boyutlar hem fiziksel mekân hem de sanal mekânlar çerçevesinde incelenmiş ve bu amaçla çevre psikolojisindeki araştırmalardan yararlanılmıştır. Böylece, okunabilirlik yapısının daha detaylı anlaşılabilmesi için daha kapsamlı bir yaklaşım sağlandığı düşünülmektedir.

Hizmet uzantısı olarak tanımlanan okunabilirlik yapısının kapsamında yer alan boyutların belirlenebilmesi amacıyla bir ölçek geliştirilmiştir. Bu kapsamda öncelikle pazarlama, turizm, çevre psikolojisi ve çevre estetiği alanlarında yazın taraması yapılmıştır. Yazın taraması ile okunabilirlik boyutları belirlenmiş ve bu boyutları oluşturan ifadeler geliştirilmiştir. İzlenen bu aşamalar sonucunda 32 maddeden oluşan okunabilirlik ölçeği geliştirilmiştir. Ölçeğin kapsam geçerliği ve güvenirliği değerlendirildikten sonra madde sayısı 30'a indirilmiştir. Yapılan analizler sonucu okunabilirlik yapısını açıklayan altı boyuta ulaşılmış ve ölçeğin yapı güvenirliği ve birleşik güvenirliklerinin yeterli olduğu doğrulanmıştır. Sonuç olarak, bir seminer etkinliğinin okunabilirliğini belirleyen altı faktör tanımlanmıştır. Bu altı boyut organizasyonel açıklık, yol ve yön bulma, işaretlendirme, mekânsal düzenleme, bilgilendirme ve araçlar olarak isimlendirilmiştir.
Çalışmada ortaya çıkarılan okunabilirlik boyutları ile konuyla ilgili kuram ve çalışmaları destekleyen sonuçlara ulaşılmıştır. Öncelikle bireyleri çevre tercihlerinin insan türünün gelişim aşamaları içinde izini sürmeye odaklanmış evrimci estetik kapsamında okunabilirliği açıklayan Kaplan ve Kaplan (1979; 1987; 1992; 1995) belirli çevreler ve mekânlara ilişkin temel bilgi ihtiyacının bireylerin tercihlerini etkilediğini bu nedenle "açıklığın" bireyin çevreyi/mekânı tercih etmesi ve yorumlayabilmesi ile ilişkili önemli bir unsur olduğunu belirtmişlerdir. Benzer şekilde bu yaklaşımın bir etkinlik deneyimi için de geçerli olduğu anlaşılmaktadır. Çalışmada bir etkinliğin en belirgin okunabilirlik boyutu "organizasyonel açıklık" olarak belirlenmiştir. Bilindiği üzere bir etkinliğin web sitesi seminer katılımcılarını bilgilendiren ve potansiyel deneyimlerine hazırlayan sanal bir çevre olarak ele alınabilmektedir. Bununla birlikte hazırlanan etkinlik programının sağladığ deneyiminin şekillenmesinde bir diğer unsur olarak tanimlanabilmektedir. Bu nedenle web sitesi ve etkinlik programında katılımcılarına sunulan bilgiler, bu bilgilerin organizasyonu, sunumu ve miktarı katılımcıların etkinlik deneyimini anlayabilmeleri ve yorumlayabilmelerini sağlamaktadır.

Çalışmada etkinliğin okunabilirliğini sağlayan diğer boyutlar; yol ve yön bulma, işaretlendirme ve mekânsal düzenleme olarak belirlenmiş ve bu sonuçların önceki çalışmalar ile örtüştüğü görülmektedir (Foxall ve Hacket 1994; Newman 2007). Elde edilen bu sonuçlar, Kevin Lynch'in şehirler için sunduğu klasik yaklaşımın etkinlik deneyimi için de geçerli olduğunu göstermektedir. Lynch'in (1960: 49) bir şehrin ya da mekânın okunabilirliği için gösterdiği temel ilke, bireylerin mekânsal düzenlemeleri ve işaretlendirmeleri kolay bir şekilde anlayabilmeleri ve etkin bir şekilde yollarını ve yönlerini bulmalarıdır. Benzer şekilde seminerin düzenlendiği otelin mimarisinin katılımcıların otel içinde yollarını ve yönlerini bulmalarını sağlaması ve otelde kullanılan seminer salonlarının mekânsal düzenlemesi etkinliğin okunabilirliğine yardımc1 olmaktadır. Ayrıca etkinliğin düzenlendiği destinasyonda yer alan trafik işaretleri, tabelalar, yönlendirme ve bilgilendirme işaretleri gibi destinasyon işaretlendirme sisteminin kolay anlaşılabilmesi etkinliğin okunabilirliğini sağlayan unsurlar olduğu görülmektedir. Bu noktada bir etkinliğin gerçekleştiği otelin ve destinasyonun seçiminin et- 
kinlik deneyiminde önemli bir unsur olduğu söylenebilmektedir.

Okunabilirlik kavramına ilişkin yapılan önceki araştırmalardan farklı olarak bu çalışmada, etkinliğin düzenlendiği destinasyonun anlaşılmasını, destinasyonda yol ve yön bulunmasını sağlayan harita gibi etkenleri içeren "araçlar" boyutu bir etkinliğin okunabilirliğini sağlayan unsurlar olarak belirlenmiştir.

Etkinliklerin soyut doğası nedeniyle potansiyel katılımcılar satın alma öncesi bir etkinlik deneyimini deneyemediği ya da bir örneğini göremedikleri için ilk izlenim oldukça kritik bir öneme sahiptir. Bu noktada etkinlik yöneticilerinin etkinliğe ait web sitesinin tasarım ve düzenine önem vermeleri, sunulan bilgiyi anlaşılabilir ve yeterli düzeyde sağlamaları potansiyel katılımcıların satın alma kararını vermelerini kolaylaştıracak, etkinliğe yönelik yüksek kalite algısı oluşturacak ve henüz deneyimleyemedikleri etkinlik hakkında katılımcılarda olumlu bir algı oluşturulmasını sağlayacaktır.

Çalışmada etkinliğin gerçekleştiği destinasyon ve mekanın, etkinliğin okunabilirliğinde önemli unsurlar olduğu belirlenmiştir. Bu nedenle katılımcılarına zengin bir etkinlik deneyimi sunmak isteyen etkinlik yöneticilerine destinasyon seçim sürecinde, destinasyonun işaretlendirme gibi çevresel düzenlemeleri ile birlikte destinasyonun anlaşılmasını sağlayacak araçların bulunmasına dikkat etmeleri önerilebilir. Bununla birlikte etkinliğin gerçekleştirileceği otelin mimarisinin ve seminer için kullanılacak salonların mekânsal düzenlemelerinin otel seçiminde ön planda bulundurulması gerektiği düşünülmektedir.

Bir etkinliğin okunabilirliğini sağlayan faktörleri doğru anlamak, etkinlik planlayıcılarının ve pazarlamacılarının katılımclarının deneyimlerinin planlanması ve etkinlik süresince deneyimlerinin yönlendirilmesini sağlayacaktır.

Bir etkinliğin okunabilirlik boyutlarının belirlenmesi amacıyla yapılan bu çalışmada okunabilirliğin katılımcılar üzerindeki etkileri, araştırma d1şında tutulmuştur. Gelecekte duygusal ve bilişsel etkiler ile birlikte davranışsal sonuçları kapsayacak şekilde çalışmaların yapılması, okunabilirlik boyutlarının katılımcilar üzerindeki etkilerinin sınanmasını sağlayabilir. Bu çalışma ile birlikte belirlenen okunabilirlik boyutları; festival, spor etkinlikleri gibi farklı etkinlik türlerinde değerlendirilebilir.

\section{KAYNAKÇA}

Anderson, J. C. ve Gerbing, D. W. (1982). Some Methods for Respecifying Measurement Models to Obtain Unidimensional Construct Measurement, Journal of Marketing Research, 19 (4): 453-460.

Anderson, J. C. ve Gerbing, D. W. (1988). Structural Equation Modeling in Practice: A Review and Recommended TwoStep Approach, Psychological Bulletin, 103: 411-423.

Bitner, M. J. (1992). Servicescapes: The Impact of Physical Surroundings on Customers and Employees, The Journal of Marketing, 56 (2): 57-71.

Bonn, M. A., Joseph-Mathews M. S., Dai, M.,Hayes, S. ve Cave, J. (2007). Heritage/Cultural Attraction Atmospherics: Creating The Right Environment for The Heritage/Cultural Visitor, Journal of Travel Research, 45: 345-354.

Chang, K. (2000). The Impact of Perceived Physical Environments on Customers' Satisfaction and Return Intentions, Journal of Professional Services Marketing, 21 (2): 75-85.

Churchill, G. A. (1979). A Paradigm for Developing Better Measures ff Marketing Constructs, Journal of Marketing Research, 1681: 64-73.

Countryman, C. C. ve Jang, S. (2006). The Effects of Atmospheric Elements on Customer Impression: The Case of Hotel Lobbies, International Journal of Contemporary Hospitality Management, 18 (7): 534-545.

Deng, L. ve Poole, M. S. (2012). Aesthetic Design of E-Commerce Web Pages-Webpage Complexity, Order and Preference, Electronic Commerce Research and Applications, 11: 420-440.

Donovan, R. J. Rossiter, J. R., Marcoolyn, G. ve Nesdale, A. (1994). Store Atmosphere and Purchasing Behavior, Journal of Retailing, 10 (3): 283-294.

Edwards, J. S. A. ve Gustafsson, I. (2008). The Room and Atmosphere as Aspects of the Meal: A Review, Journal of Food Service, 19: 22-34.

Ezeh, C. ve Haris, L. C. (2007). Servicescape Research: A Review and A Research Agenda, The Marketing Review, 7 (1): 59-78.

Foxall, G. ve Hackett, P. (1994). Consumer Satisfaction with Birmingham's International Convention Centre, Service Industries Journal, 14 (3): 369-380.

Gerbing, D. W. ve Anderson, J. C. (1988). An Updated Paradigm for Scale Development Incorporating Unidimensionality and its Assessment, Journal of Marketing Research, 25: 186-192.

Hair, J. F., Anderson, R. E., Tahtam, R. L. ve Black, W. C. (1995). Multivariate Data Analysis with Readings. 4. Bask1, Englewood Cliffs, N. J.:Prentice-Hall.

Heide, M. ve Grønhaug, K. (2006). Atmosphere: Conceptual Issues and Implications for Hospitality Management, Scandinavian Journal of Hospitality and Tourism, 6 (4): 271-286.

Hightower, R., Brady, M. K. ve Baker, T. L. (2002). Investigating The Role of The Physical Environment in Hedonic Service Consumption: An Exploratory Study of Sporting Events, Journal of Business Research, 55: 697-707.

Jang (Shawn), S. ve Namkung, Y. (2009). Perceived Quality, Emotions, and Behavioral Intentions: Application of an Extended Mehrabian-Russell Model for Restaurants, Journal of Business Research, 62 (4): 1-10.

Kaplan, S. (1978). Aesthetics, Affect and Cognition: Environmental Preference From an Evolutionary Perspective, Environment and Behavior, 19 (1): 3-32. 
Kaplan, S. (1979). Perception and Landscape: Conceptions and Misconceptions, National Conference on Applied Techniques for Analysis and Management of the Visual Resource, Incline Village, Nevada, Nisan 23-25, http:// www.fs.fed.us/psw/publications/documents/psw gtr035/psw gtr035_05_s-kaplan.pdf, Erişim tarihi: 23.03.2010.

Kaplan, S. (1995). Environmental Preference in a Knowledge-Seeking, Knowledge-Using Organism. The Adapted Mind: Evolutionary Psychology and The Generation of Culture. Ed: J. H. Barkow, L. Cosmides ve J.Tooby, ABD: Oxford Üniversitesi Yayınları.

Kaplan, S. ve Kaplan, R. (1978). Humanscape: Environments for People. North Scituate, Mass.: Duxbury Yayınları.

Kim, W. G. ve Moon, Y. J. (2009). Customers' Cognitive, Emotional, and Actionable Response to the Servicescape: A Test of the Moderating Effect of the Restaurant Type, International Journal of Hospitality Management, 28: 144-156.

Kotler, P. (1973). Atmospherics as a Marketing Tool, Journal of Retailing, 49 (4): 48-64.

Köseoğlu, E. (2012). Formal, Syntactical and Subjective Dimensions of Spatial Legibility in Configurationally Differentiated Patterns, (Yayımlanmamış Doktora Tezi), Yıldız Teknik Üniversitesi.

Kwortnik, R. J. (2008). Shipscape Influence on the Leisure Cruise Experience, International Journal of Culture, Tourism and Hospitality Research, 2 (4): 289-311.

Lee, Y-K., Lee, C-K., Lee, S-K. ve Babin, B. J. (2008). Festivalscapes and Patrons' Emotions, Satisfaction, and Loyalty, Journal of Business Research, 61: 56-64.

Lynch, K. (1960). The Image of a City. Cambridge. MA: MIT Press.

McDonnell, A. ve Hall, C. M. (2008). A Framework for the Evaluation of Winery Servicescape: A New Zealand Case, PASOS Revista de Turismo Patrimonio Cultural, 6 (2): 231-247.

Namasivayam, K. ve Mattila, A. S. (2007). Accounting for the Joint Effects of the Servicescape and Service Exchange on Consumers' Satisfaction Evaluations, Journal of Hospitality $\mathcal{E}$ Tourism Research, 31 (1): 3-18.

Nasar, J. L. (1984). Visual Preferences in Urban Street Scenes: A Cross-Cultural Comparison between Japan and The United States, Journal of Cross-Cultural Psychology, 15: 79-93.

Nasar, J. L. (1994). Urban Design Aesthetics: The Evaluative Qualities of Building Exteriors, Environment and Behavior, 26 (3): $377-401$.

Nasar, J. L. (2000). The Evaluative Image of Places. İçinde; W. B. Walsh, K. H. Craik ve R. H. Price (Editörler) Person-environment Psychology. Lawrence Erlbaum Associates, Mahwah, NJ.

Newman, A. J. (1995). Is the Way-Forward Bright?, Professional Marketing, 3 (5):24-25.
Newman, A. J. (2007). Uncovering Dimensionality in the Servicescape: Towards Legibility, The Service Industries Journal, 27 (1): $15-28$

Oostendorp, A. ve Berlyne, D. E. (1978). Dimensions in the Perception Of Architecture: Identification and Interpretation of Dimensions of Similarity, Scandinavian Journal of Psychology, 19: 73-82.

Passini, R. (1984). Wayfinding in Architexture. New York: Van NostrandReinhold.

Ryu, K. ve Jang, S. S. (2007). The Effect of Environmental Perceptions on Behavioral Intentions Through Emotions: The Case of Upscale Restaurants, Journal of Hospitality $\mathcal{E}$ Tourism Research, 31 (1): 56-72.

Schermelleh-Engel, K., Moosbrugger, H. ve Müller, H. (2003). Evaluating the Fit of Structural Equation Models: Tests of Significance and Descriptive Goodness of Fit Measures, Methods of Psychological Research Online, 8 (2): 23-74.

Sim, J., Mak, B. ve Jones, D. (2006). A Model of Customer Satisfaction and Retention for Hotels, Journal of Quality Assurance in Hospitality \& Tourism, 7 (3): 1-23.

Titus, P. A. ve Everett, P. B. (1995). The Consumer Retail Search Process: A Conceptual Model and Research Agenda, Journal of the Academy of Marketing Science, 23 (2): 106-119.

Turley, L. W. ve Milliman, R. E. (2000). Atmospheric Effects on Shopping Behaviour: A Review of the Experimental Evidence, Journal of Business Research, 49: 193-211.

Wakefield, K. L. ve Blodgett, J. G. (1994).The Importance of Servicescapes in Leisure Service Settings, Journal of Services Marketing, 8 (3): 66-76.

Wakefield, K. L. ve Blodgett, J. G. (1999). Customer Response to Intangible and Tangible Service Factors, Psychology $\mathcal{E}$ Marketing, 16 (1): 51-68.

Wakefield, K. L., Blodgett, J. G. ve Sloan, H. (1999). Measurement and Management of the Sportscape, Journal of Sport Management, 10: 15-31.

Wakefield, K. W. ve Baker, J. (1998). Excitement at the Mall: Determinants and Effects on Shopping Behavior, Journal of Retailing, 74 (4): 515-539.

Wall, E. A. ve Berry, L. L. (2007). The Combined Effects of the Physical Environment and Employee Behavior on Customer Perception of Restaurant Service Quality, Cornell Hotel and Restaurant Administration Quarterly, 48 (1): 59-69.

Weisman, G. (1981).Evaluating Architectural Legibility: Way finding in the Built Environment, Environment and Behavior, 13: 189-204.

Yılmaz, V. ve Çelik, H. E. (2009). LISREL ile yapısal Eşitlik Modellemesi-I. Temel Kavramlar, Uygulamalar, Programlama. Ankara: Pegem Akademi.

Zeithaml, V. A. ve Bitner, M. J. (2003). Services Marketing: Integrating Customer Focus Across The Firm. 3. Bask1, Boston: McGraw-Hill/Irwin. 